\title{
Group Types as Style Markers in J. P. Clark- Bekederemo's Poetry
}

\author{
Ebi Yeibo \\ Department of English and literary Studies, Faculty of Arts, Niger Delta University, Bayelsa State, Nigeria \\ Email: eyeibo@gmail.com
}

\begin{abstract}
Group types or word groups constitute a veritable aspect of the syntactic structure of the English Language. In Hallidayan systemic linguistics, it is placed third on the hierarchy of five grammatical units in the language, viz: sentence, clause, phrase (word group), word and morpheme, in a descending order. A fundamental aspect of these grammatical units is their mutual inclusiveness i.e a lower unit is included in a higher unit. Thus, clauses, word groups, words, morpheme form the sentence, which is the highest in the hierarchy. In this study, we have examined the structural constituents of word groups and the textual functions they perform in J.P. Clark-Bekederemo's poetry, using linguistics-stylistic parameters. The study demonstrates that, like other aspects or units of language, word groups have meaning-making potentials and play a crucial role in encoding the message of a text. It also throws light on the inexorable relationship between syntax and poetry, and adds to the ever-growing and divergent criticisms on African literature.
\end{abstract}

Index Terms - group types, style markers, J.P. Clark-Bekederemo, poetry

\section{INTRODUCTION}

It was Todorov (1977) who averred that "literature is a verbal work of art". This statement implies not only the centrality of language to any discourse on literary procreation but also the fact that, 'the verbal style includes all the devices of language that are used to achieve communication in speech and writing' (Alo, 1998, p.1). The point is that, to fully grasp the message and aesthetics of a literary text (or any text for that matter), there must be recourse to language at all levels of linguistic description, because it is the singular medium of its expression. Dada (2004) explains:

A literary work contains a lot of codes and information that must be decoded in order to fully grasp the meaning of the work; it has sound patterns, semantic relations and syntactic organization. All these must be taken into account when reading a literary text.

However, from available literature, J.P. Clark-Bekederemo's poetry has not been intensively studied from a linguistic perspective. This is in spite of the universal acclaim and wide range of criticisms that his works have evoked. In fact, most of the works on his poetry are from thematic and literary angles (Eyoh, 1997). Eyoh's (1997) J.P. Clark's Poetry: a Study in Stylistic Criticism remains the only full-scale linguistic discussion of the writer's poetry. The limitation of this work, however, is the triadic focus on the phonological, lexical and paralinguistic affective levels of languages use. According to Crystal and Davy (1969), the levels of linguistic analysis are phonetics/graphetics, phonology/graphology, grammar/lexis and semantics.

The present study seeks to fill the gap left by Eyoh's (1997) work, by focusing on word groups which is an aspect of syntax. The grammatical level is as important as any other level of linguistic description because the literary artist essentially selects lexico-grammatical options to encode his textual message (s). Hence, Dever (1978) posits that, in creating any text, literary or non-literary, we must combin words to express complex ideas or relationships in sentences. Lyons (1977) echoes a similar viewpoint inter alia “... the function of language tends to be reflected in its grammatical and lexical structure, which interrelates sentences with the feature of situation of the utterance" (p.249).

\section{THEORETICAL FoundATION/LITERATURE REVIEW}

Stylistics is the branch of linguistics that focuses on style, particularly in works of literature. Cluett and Kampeas (1979) refer to it as the judgment of "the tangible manifestation of style". According to Allan et a 1 (1988), the concept

.... studies the characteristics of situationally distinctive use of language and tries to establish principles capable of accounting for particular choices made by individuals and social groups in their use of language.

From the foregoing overview, we can see the water tight relationship between style and stylistics. It is the workshop of stylistics; the soil on which stylistics is sown. Hence, Babajide (2000) observes that where there is no style, there is no stylistics. What then is style? Basically, it refers to the way we do things - dress, talk, pray, dance, walk, etc. in a linguistic sense, the concept infers the specific manner a particular speaker or writer expresses himself. Leech and Short (1981) see it as "the way language is used in a literary text, with the aim of relating it to its artistic (aesthetic) functions" (p.14-15). According to Tomori (1977), "there is a style in everything we say; so style cannot be isolated from language itself; but it is a distinctive aspect of language" (p.53). 
Over the years various theories have been propounded by different scholars, to explicate the concept of language and its use, particularly in literary circles. This fact underscores the critical place of language in human existence, as it constitutes the bedrock of human socialization and civilization. The Russian formalism of the 1920s and the structuralist school of the 1960s, postulate the existence of a special "poetic language", as distinct from "ordinary" or "scientific" language. Wellek and Warren (1963) also distinguish a poetic use of language, in the sense that, it is non-referential, non-practical, non-casual, etc. This implies that "poetic language" is unique as a result of its conscious use of linguistic and imagistic devices to foreground aspects of meaning.

Another fundamental aspect of the language of poetry is its deviant character. The language of poetry inherently and overtly deviates from linguistic conventions or norms, at all levels of its use i.e. semantic, phonological, lexical, syntactic, etc, because poets enjoy what has been referred to as poetic license. Hence Widdowson (1984) contends that, "it is common to find instances of language use which cannot be accounted for by grammatical rules," in poetry (p.162). According to Crystal (1987), it is this deviant and abnormal feature of the language of poetry that stylistics focuses on. Chomsky's (1957) Transformational Generative Grammar (TGG), is also germane to the present discourse, as it postulates the disparity and relations between deep and surface structures. The relevant point in Chomsky's TGG is that the meaning of surface linguistic constructs like poetry is retrievable only in the deep structure. This point also underscores the fact that meaning in poetry texts is multi-layered and multi-faceted.

However, since the primary concern of the present study is on the functional aspect of language, we shall adopt M. A. K. Halliday's Systemic Functional Grammar (SFG), as our analytical model, in the sense that it focuses not only on the structure of language, but also on the properties of discourse and its functions in specific social and cultural situations. Specifically, the study adopts Halliday's three metafunctions of language viz: ideational, interpersonal, and textual for the textual analysis. The ideational metafunction focuses on the subject matter or field of discourse, while the interpersonal metafunction refers to the tenor of discourse i.e. the social relationship that exists among participants in a given discourse situation, which has the potentials to influence or shape language use. The textual metafunction is particularly relevant to our study, as it focuses on the internal organization and communicative nature of a text. The preoccupation of this study is to show how word groups are organized in J.P. Clark-Bekederemo's poetry, to foreground aspects of meaning and aesthetics in the texts.

Thus, our adoption of Halliday's Systemic Functional Grammar for textual analysis, is necessitated by its sociological and functional appeal. According to Opara (2005), Halliday's claim in this theory is that language structure reflects the social uses to which language is put. In other words, we agree with Osakwe (1995) that "the language of the poet mirrors the function and purpose of a poem - like any other linguistic text which is also dependent upon major situational factors" (p.XIV). The critical point is that the linguistic-stylistic approach that we have used in the study enables us to examine and characterize the structural and functional aspects of a writer's idiolect. Ayemoni (2004) posits that the approach offers three major benefits. Firstly, the analyst will be aware of the structural pattern of language permeating a text, to enable him identify the prominent or foregrounded stylistic features of the text. It also enables the analyst to be consciously aware of the kind of social variations, which the inherent linguistic features are identified with. Finally, the approach also enables the analyst to know the technique of putting these features down systematically in order to reveal the internal patterning of texts.

The dominant critical focus on African poetry has been on the traditional literary and thematic features of texts. Linguistic/stylistic studies are generally sparse (see Eyoh, 1997). The few works that attempt a linguistic/stylistic appraisal of poetic creations in the continent include: Anozie's (1985) "Equivalent Structures in Soyinka's Poetry: Toward a Linguistic Methodology in African Poetry Criticism," Ofuani's (1987) A Stylistic Analysis of Okot P'Bitek's Poetry, Osakwe's (1992) The Language of Wole Soyinka's Poetry: A Diatype of English, Adejare's (1992) Language and Style in Soyinka: A Systemic Textlinguistic Study of a Literary Idiolect, Eyoh's (1997) J.P Clark-Bekederemo's Poetry: A Study in Stylistic Criticism, Edonmi's (2000) A Text-Linguistic Enquiry into Osundare's Poetic Idiolect, and Ushie's (2001) Many Voices, Many Visions: A Stylistic Study of 'New' Nigerian Poetry.

\section{THE CONCEPTS OF GROUP TYPE AND STYLE MARKER}

The concept of word group or phrase is an aspect of syntax. According to Dever (1978), syntax describes:

... the way in which we arrange words like "building blocks" to construct sentences that express our ideas. Syntax is that part of grammar which specifies rules for sequencing or ordering words to form phrases and sentences.

The 'building blocks' referred to in the above definition refer to the morphemes, words, phrases (groups) and clauses, which constitute sentences. According to Alo (1995), group refers to "a group of words with no subject or predicate of its own”. In Douglas' (2004) view, it is “ a sequence of words, which belong together grammatically”. Babajide (1996) sees the concept as:

... a group of words which serves as a single part of speech. It has neither a subject nor a finite verb ... (it) expresses fragmentary thoughts rather than complete thoughts.

Alo (1995) posits that classifications of word groups include (a) nominal group (i.e the boys, the two cars, the cleaner in the office), verbal group (i.e can go, must have gone), (c) prepositional group (i.e in the office, behind the bar, on the table), (d) adjectival group (i.e very happy, too tired), adverbial group (i.e very soon). 
Style markers, on the other hand, are those linguistic features deliberately deployed in a given text or discourse by an author, to encode aspects of meaning and also achieve particular aesthetic effects. They are the linguistic features of texts which are significant for their semantic implications and aesthetic functions. In other words, for an aspect of language use to be considered a style marker in a particular text, it must have visual and imaginative appeal or effect on the reader or audience. An identification of style markers in textual analysis is expedient since it is not possible or useful to explore all the linguistics choices made by a given author. Olujide (2002) explains this view inter alia:

For the purpose of selecting stylistic features, style markers (salient features of style) are used. Once these have been identified, whole areas of language which are not used in any unusual way in a text are ignored, since no author can use all the aspects of a language code in a particular text.

The foregoing implies that stylistic analysis focuses on the significant, salient or foregrounded aspects of an author's linguistic coding in a text, in relation to the social or pragmatic contexts. It involves the identification, description and interpretation of linguistics features which stand out within a text, whether they conform to the common core of language use or are used in a deviant form.

\section{TeXtual AnAlysis}

It is practically impossible to analyse all the group components of poems of J.P. Clark-Bekederemo which span about fifty years (1958 - to date), in a study of this nature. So, ten poems which are randomly selected across three collections, in order to account for each of the group types (i.e nominal, adjectival and prepositional) will be considered shortly. The three collections viz: Poems (1962), of Sleep and Old Age (2003) and Once Again a Child (2004), have been chosen essentially to achieve a temporal balance between his early and latest poetry. It should also be pointed out here that greater emphasis shall be placed on the structural peculiarities of the groups but also with due attention to their functions or textual roles.

\section{A. The Nominal Group}

In line with Systemic Functional Grammar, the word class noun heads the nominal group with one or more modifications before or after it. Four structural possibilities of the nominal group are often identified: the ' $H$ ' type which is made up of only a nominal head; the'Mh' type, with modification (s) before the head; the 'hq' type with qualification(s) after the head and 'mhq' type with all the basic elements present (i.e the pre and post modifiers, plus the head). In order to determine the type(s) that are dominant in J.P. Clark-Bekederemo's poems under study, we analyse the first noun phrase to occur in each of the ten poems under study. The result is presented in the form of a table below:

\begin{tabular}{|l|l|l|l|}
\hline \multicolumn{2}{|l|}{ NOMINAL GROUP TEXT } & SOURCE & $\begin{array}{l}\text { STRUCTURAL } \\
\text { ANALYSIS }\end{array}$ \\
\hline 1 & A courtyard & "My Father's House" (Of Sleep and old Age $)$ & Mh \\
\hline 2 & The photograph of an old man & "A Photograph" (Of Sleep ...) & Mhq \\
\hline 3 & The active state & "A Time to Sleep" (Of Sleep ...) & Mhq \\
\hline 4 & My first impression of my father & 'My Father in his Thirties $($ Once Again ...) & Mhq \\
\hline 5 & My first outbreak of fire & "My First Fire (Once Again ...) & Mhq \\
\hline 6 & The mysteries of a people & "Lions and Leopards in the Night' (Once Again a Child) & Mhq \\
\hline 7 & ...a wife in the compound & "The Snake killer" (Once Again a Child $)$ & Mhq \\
\hline 8 & The throb of a drum & "Agbor Dancer" (Poems) & Mhq \\
\hline 9 & The generals in the field & "Return of the Heroes" (Poems) & Mhq \\
\hline 10 & The interest of the public & "Victoria Island" (Poems) & Mhq \\
\hline
\end{tabular}

As indicated in the table above, the nominal groups in the sampled poems are dominantly 'Mhq' type. Only ten percent is ' $\mathrm{Mh}$ ' type and there is neither ' $h q$ ' nor ' $h$ ' type nominal group. This statistics is stylistically significant: the group type endows the poems with the qualities of simplicity, clarity and concreteness. Semantically speaking, 'Mhq' nominal group is more detailed and more explicit than other nominal group types. This is because the modifier and the qualifier elements of the nominal group perform adjectival functions clarifying the meaning of the noun head, with which they are structurally related.

In addition, the nominal group type that is dominant in the poems helps in reducing the heuristic task of readers as it frees the poems from ambiguity. If we consider the text in the table above, we will appreciate the discourse function of the 'Mhq' nominal group type described above. The expression "A courtyard" is certainly a hang-over expression. Similarly, the 'Mh' nominal group in " 3 " above lacks the sort of clarity noticeable in $4-10$.

Considering the group pattern discussed above, it can be said that the poems in the selections are simple; suggesting also that simplicity is one of the stylistic peculiarities of the poems. It is also indicative of the narrative style adopted by the poet, particularly the poems in Once Again Child; Of Sleep and Old Age and A Lot from Paradise, which are all poems derived from recollection of past experience.

\section{B. The Adjectival Group}

The adjectival group is headed by the word class, adjective in the complement position within the clause structure. One of the general features of the adjectival group is that it is an element within a nominal group. When it occurs so, it is often regarded as an epithet. An adjectival group can also serve or function as the complement within a clause 
structure. We refer to this latter category of adjectival group as completive adjectival group. In what follows shortly, we shall examine in greater details the structures and functions of the sampled specimens of the structure. Like we did above, the data is first presented in the form of a table:

\begin{tabular}{|l|l|l|l|}
\hline \multicolumn{2}{|l|}{ GROUP TEXT } & SOURCE & FUNCTIONS \\
\hline 1 & Honey fresh milk fang & "Ivbie or oya: a song of wrong" (poems) & Pre-modifier \\
\hline 2 & ..the alligator is stark deaf & "The Reign of Crocodile" (poems) & Complement of the clause \\
\hline 3 & A tree in a mad act & "Dirge" (Poems) & Modifier (post) \\
\hline 4 & One person' pain is dead wood & $\begin{array}{l}\text { "When My Father Fell ill" } \\
\text { (Once Again a child) }\end{array}$ & Complement of the clause \\
\hline 5 & I only saw the cracked and broken floor & "Shadow in a Mirror" (Once Again a child) & Modifier (pre) \\
\hline 6 & $\ldots$ dry coconut shells & "War Effort" (Once Again a Child) & Modifier (post) \\
\hline 7 & A courtyard. Once like a market & "My Father's House" (Of Sleep and Old Age) & Modifier (post) \\
\hline 8 & They flew proud colourful flags & $\begin{array}{l}\text { "The Traffic Then and Now" (Of Sleep and Old } \\
\text { Age) }\end{array}$ & Modifier (post) \\
\hline 9 & A whole new world of works & "Again the Characters" (Of Sleep ...) & Modifier (pre) \\
\hline 10 & $\ldots$. a wet bare floor & "The Dead as They Lay" (Of Sleep ...) & Modifier (pre) \\
\hline
\end{tabular}

As shown in the table above, the adjectival groups are dominantly modifiers of nominal head. Only twenty percent (20\%) of the sampled text is clause complement. The modifier types are dominated by the pre-modifier category. This suggests that the adjectival groups are dominantly left-branched. A closer examination of some of them is necessary here in order to reveal their internal structure.

In ii above, the adjectival group underlined is the complement of the equative copular 'is.' The tree diagram below reveals this:

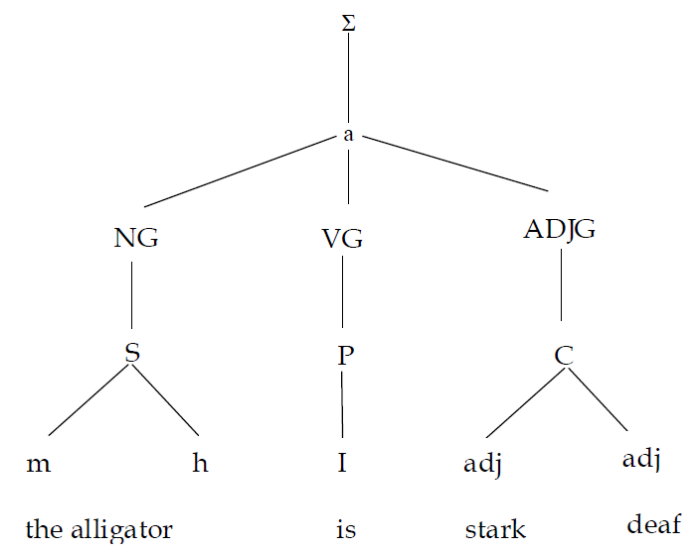

As shown in the tree diagram above, the adjectival group is made up of two 'h' type adjectival groups, "stark" and "deaf". Their combination in the group makes the description to be more splendid. This contributes to the effect which (the group) generates in readers. As could be noted, each of the groups can stand alone. As it were, 'stark' is a modifier of 'deaf'; giving it extra degree of quality.

Similarly, in $\mathrm{v}$, the adjectival group underlined is a pre-modifier of the nominal head "floor". The tree diagram of the group below reveals its internal structure:

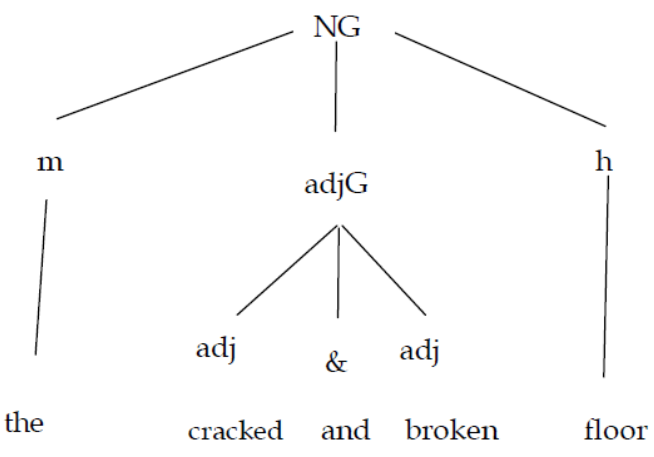


As the tree diagram analysis above reveals, the only structural difference between the adjectival group in "ii" and the adjectival group in ' $v$ ' is that the compound adjectives functioning in the latter group are connected by a linker, indicating clearly that each of them is an independent adjectival group, separable and substitutable for each other.

A closer study of the table reveals one adjectival group exhibiting a different outlook. That is the structure 'iii' above- in a mad act. This expression has the structure: preposition + nominal group, which shows (because it is headed by a preposition) that it is a prepositional group. However, functionally, it is simply an adjective describing the nominal group "the tree". The expression can also be treated as an elliptical adjectival clause - "which is a mad act". This would now yield the tree diagram analysis below:

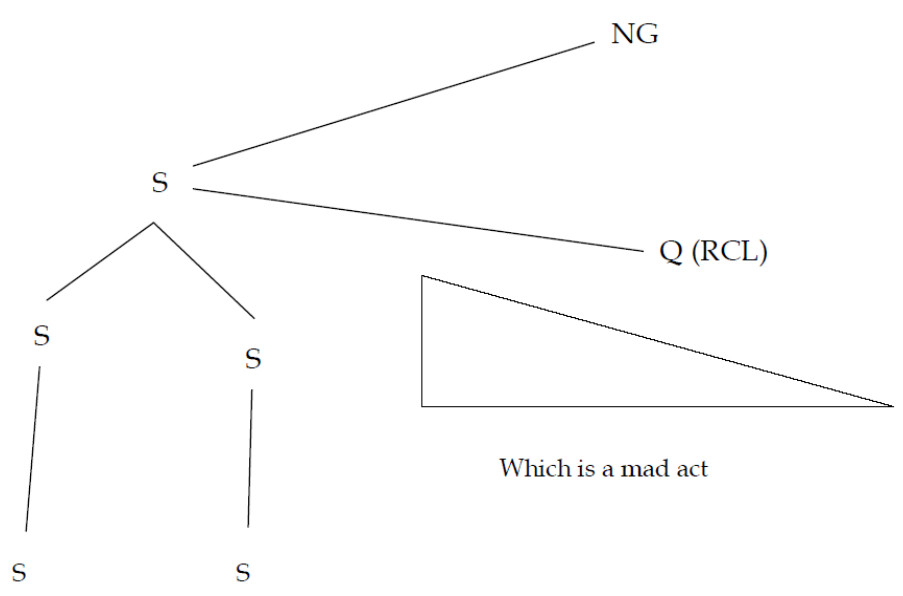

The distribution in the table above shows that structurally ambiguous patterns like the one above are very rare in J.P. Clark-Bekederemo's poems under study. This shows that simplicity and clarity of expression are marks of his poetic style.

\section{The Prepositional Group}

The prepositional group is a group whose headword belongs to the word class-preposition - such as in, at, of, on, of, off, out etc. It is the only one in the groups in English headed by a word traditionally classified as a grammatical rather than a lexical item. It is on this basis that our analysis here will focus on the semantic functions of the structure in the sampled poems. Some of the general semantic functions of prepositions include: expression of viewpoint, focusing, manner, instrument, place and time. In what follows here, we draw specimens of the structure from the poems and explain them in relation to the semantic functions they perform in the texts, first in tabular form:

\begin{tabular}{|c|c|c|c|}
\hline \multicolumn{2}{|c|}{ EXPONENT OF THE TEXT } & \multirow{2}{*}{$\begin{array}{l}\text { SOURCE } \\
\text { "Service" (poems) }\end{array}$} & \multirow{2}{*}{$\begin{array}{l}\text { SEMANTIC } \\
\text { FUNCTION } \\
\text { Time adjectival } \\
\end{array}$} \\
\hline 1. & In the slot (a clime in the slot) & & \\
\hline 2. & $\begin{array}{l}\text { In the wind (the leaves, so golden, shower in the } \\
\text { wind) }\end{array}$ & "Two Moods of Princeton" (poems) & Place \\
\hline 3. & In his den (they killed the lion in his den) & "What the squirrel said" (poems) & Place \\
\hline 4. & $\begin{array}{l}\text { In a compound (a woman now lives alone in a } \\
\text { compound) }\end{array}$ & "The Last of Wives (Of Sleep and Old Age) & Place \\
\hline 5. & $\begin{array}{l}\text { In my sleep (the many faces I see again and again } \\
\text { in my sleep) }\end{array}$ & "The Dream Peoples" (Of Sleep and Old Age) & Place \\
\hline 6. & $\begin{array}{l}\text { In the day ( a } \mathrm{m} \text { an I have come late in the day to } \\
\text { call my friends) }\end{array}$ & $\begin{array}{l}\text { "A Friend Refusing Surgery” (Of Sleep and Old } \\
\text { Age) }\end{array}$ & Time \\
\hline 7. & $\begin{array}{l}\text { In my sea son of dust (reading again, in my season } \\
\text { of dust) }\end{array}$ & “A Certain Guest' (Once Again Child) & Modifier (post) \\
\hline 8. & $\begin{array}{l}\text { Into town (where a certain guest came any day } \\
\text { into town) }\end{array}$ & "Lost Rites" (Once Again a Child) & Place \\
\hline 9. & $\begin{array}{l}\text { At home ( the many rites of passage I went } \\
\text { through as a child at home) }\end{array}$ & "Lost Rites" (Once Again a Child) & Place \\
\hline 10 & $\begin{array}{l}\text { At school (of the many films we were fed on at } \\
\text { school) }\end{array}$ & "Wining the War" (Once Again a Child) & Place \\
\hline
\end{tabular}

The table above shows clearly that the sampled poems are dominated by prepositional groups whose function is expression of time and place. This pattern can be related to the poet's interest in relating events to time and place. It also makes the poems to be more picturesque and narratively concrete. We cannot overlook the structural peculiarity of the distribution of the prepositional groups in these poems. As could be noted, $80 \%$ of the sampled prepositional groups are headed by 'in', while just $20 \%$ is headed by 'at.' The 'at' headed prepositional groups serve to connect events in the poems to places not big enough to be modified by the preposition 'in'. This reflects or marks the poet's adherence to the rule of appropriateness in language use in spite of his license, as a poet, to use language in a deviant form. 


\section{CONCLUSION}

In this study, we have examined the structural constituents of group types and the textual roles they play in J.P. Clark-Bekederemo's poetry. Essentially, we have shown that the poet's style is foregrounded by the utilization of structural devices such as group types for encoding the meaning of his texts. Thus, we agree with Ofuani (1987) that the relationship between the structure of a poem and its semantic content is that the poem means what it means largely because of its structure.

\section{REFERENCES}

[1] Allan, B.et al (Eds) (1988). The Fontana Dictionary of Modern Thoughts. London: Fontana.

[2] Alo, M. (1995). Applied English linguistics: An Introduction. Port Harcourt: Aeddy Link.

[3] Alo, M. (1998). Style in Language and Communication. Port- Harcourt: Aeddy Link.

[4] Adejare, O. (1992). Language and Style in Soyinka: A Systemic Textlinguistic Study of a Literary Idiolect. Ibadan: Heinemann.

[5] Anozie, S.O. (1985). "Equivalent Structures in Soyinka's Poetry: Toward a Linguistic Methodology in African Poetry Criticism". In Research in African Literatures. Vol. 16, No 1, 21-35.

[6] Ayeomoni, M.O. (2004). “A linguistic-stylistic Investigation of the Language Of the Nigeria Political Elite.” In L. Oyeleye (Ed) Language and Discourse in society. Ibadan: Hope.

[7] Babajide, A. (1996). Introductory Grammar and Writing Skills. Ibadan: Enicrowrifit

[8] Babajide, A. (2000). "Of Style and Stylistics". In A. Babajide (Ed) Studies in English Language. Ibadan: Enicrowrifit.

[9] Clark-Bekederemo, J.P. (1962). Poems. Ibadan: Mbari.

[10] Clark-Bekederemo, J.P (2003). Of Sleep and Old Age. Lagos: Crucible.

[11] Clark-Bekederemo, J.P. (2004). Once Again a Child. Ibadan: Mosuro.

[12] Cluett, E \& kampeas, R. (1979). Glossly speaking. Toronto: Discourse Associates.

[13] Crystal, D. (1987). The Cambridge Encyclopedia of Language. Cambridge: CUP.

[14] Crystal, D. and Davy, D. (1969). Investigating English Style. London: Longman.

[15] Dada, P.O. (2004). English and Literary Stylistics. Makurdi: Abogom

[16] Dever, R. (1978). Talk: Teaching the American Language to Kids. Columbus: Merril.

[17] Douglas, O.D. (2004). "Language and Style in E.R. Braithwaite's To Sir, with Love. In L. oyeleye (Ed) language and Discourse in Society. Ibadan: Hope.

[18] Eyoh, L. (1997). J.P. Clark-Bekederemo's Poetry: A Study in Stylistic Criticism. An Unpublished Ph.D Thesis, University of Port-Harcourt, Nigeria.

[19] Halliday, M.A.K. (1970). "Language Structure and Language Function”. In Lyons, J. (Ed.) New Horizons in Linguistics. Harmondswoth: Penguin Books.

[20] Halliday, M.A.K. (1971). "Linguistics and Literary Style". In An Inquiry into the Language of William Golding. London: Edward Arnold.

[21] Halliday, M.A.K. (1973). Explorations in the Functions of Language. London: Edward Arnold.

[22] Halliday, M.A.K. (1978). Language as a Social Semiotic: The Social Interpretation of Language and Meaning. London: Edward Arnold.

[23] Leech, Geoffrey. (1969). A Linguistic Guide to English Poetry. London: Longman

[24] Leech, G.N \& Short, M.H. (1981). Style in Fiction. A Linguistic Introduction to English Functional Prose. Cambridge: CUP.

[25] Lyons, J. (1977). Semantics (Vols 1 \& 2). Cambridge: CUP

[26] Miller, R. and Currie, I. (1970). The Language of Poetry. London: Heinemann Books Ltd.

[27] Ofuani, O. (1987). A Stylistic Analysis of Okot P 'Bitek's Poetry. An Unpublished Ph.D. Thesis, University of Ibadan, Nigeria.

[28] Ogbulogo, C. (2005). Concepts in Semantics. Lagos: Sam Iroanusi Publications.

[29] Ogunsiji, A. (2000). "Introductory Semantics". In Babajide, A.O. (ed) Studies in English Language. Ibadan: Enicrownfit Publishers.

[30] Osakwe, M.I. (1992). The Language of Soyinka's Poetry: A Diatype of English. An Unpublished Ph.D Thesis, University of Ibadan, Nigeria.

[31] Osundare, N. (2003). Cautious Paths through the Bramble: A Critical Classification of Style Theories and Concepts. Ibadan: Hope Publishers.

[32] Sweeney, E. (1979). Another Country: The Land of Literature. Enugu: Fourth Dimension Publishers.

[33] Todorov, T. (1977). The Poetics of Prose. New York: University Press.

[34] Ushie, J. (2001). Many Voices, Many Visions: A Stylistic Study of 'New' Nigerian Poetry. An Unpublished Ph.D. Thesis, University of Ibadan, Nigeria.

[35] Waudaugh, R. (1986). An Introduction to Sociolinguistics. Oxford: Blackwell.

[36] Wellek, R. and Warren, A. (1977). The Language of Literature. London: Longman 


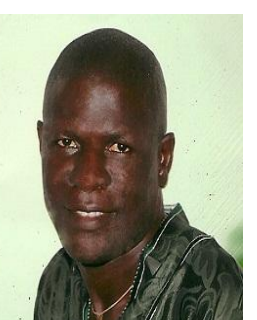

Ebi Yeibo was born in Bomadi, Delta State, Nigeria, on February 24, 1969. He obtained degrees in English from the Delta State University, Abraka (1996) and the University of Ibadan (2000), Nigeria, specializing in discourse analysis and stylistics.

He teaches stylistics, discourse analysis, applied linguistics, semantics and history of the English language at the Niger Delta University, Wilberforce Island, Bayelsa State, Nigeria, and has published scholarly papers on these areas in local and international journals. An award-winning poet, his published volumes of poetry include: Maiden Lines (Ibadan: Akol Press, 1997), A Song for Tomorrow (Ibadan: Kraftbooks Ltd, 2003), and The Forbidden Tongue (Ibadan: Kraftbooks Ltd, 2007).

Mr. Yeibo is a member of various professional and learned associations in Nigeria: Association of Nigerian Authors (ANA), Linguistic Association of Nigeria (LAN), and Nigerian Institute of Public Relations (NIPR). 